\title{
CHEMISTRY
}

\section{CHEMICAL TYPIFICATION AND GENETIC CRITERIA FOR THE COMPOSITION OF GEORGIAN PETROLEUM}

\author{
Natela Khetsuriani, \\ Doctor, Head of the Laboratory of Petroleum Chemistry, chief research worker, Tbilisi State \\ University, Petre Melikishvili Institute of Physical and Organic Chemistry, Tbilisi, Georgia
}

Vladimer Tsitsishvili,

Academician, Professor, chief research worker, Tbilisi State University, Petre Melikishvili Institute of Physical and Organic Chemistry, Laboratory of Petroleum Chemistry, Tbilisi, Georgia

\section{Elza Topuria,}

PhD, chief research worker, Tbilisi State University, Petre Melikishvili Institute of Physical and Organic Chemistry, Laboratory of Petroleum Chemistry, Tbilisi, Georgia

\section{Madlena Chkhaidze,}

MS, scientific worker; Tbilisi State University, Petre Melikishvili Institute of Physical and Organic Chemistry, Laboratory of Petroleum Chemistry, Tbilisi, Georgia

\section{Irina Mchedlishvili,}

MS, scientific worker, Tbilisi State University, Petre Melikishvili Institute of Physical and Organic Chemistry, Laboratory of Petroleum Chemistry, Tbilisi, Georgia

DOI: https://doi.org/10.31435/rsglobal_ws/31052020/7074

\section{ARTICLE INFO}

Received: 29 March 2020

Accepted: 03 May 2020

Published: 31 May 2020

\section{KEYWORDS}

crude oil, biomarkers, geochemical criteria, catagenesis, GC/MS.

\begin{abstract}
The results of investigation of molecular composition of biological markers of Eastern Georgia crude oils by methods of GLC, MS, GC/MS, genetic and geochemical aspects of their chemical composition, the main geochemical criteria for making various genetic correlations are presented. It was established that though these crude oils belong to different chemical types they all belong to a single genetic type. High concentrations of isoprenoid alkanes, ratio $\mathrm{iC}_{19} / \mathrm{iC}_{20}>1$, were revealed. In fractions higher than $420^{\circ} \mathrm{C}$ amongst the main biomarkers - steranes and triterpanes $\left(\mathrm{C}_{27}-\mathrm{C}_{33}\right)$ - prevail hopanes of the $17 \alpha \mathrm{H}$-hopan series $\left(\mathrm{C}_{30} \mathrm{H}_{52}\right)$; steranes $\left(\mathrm{C}_{27}-\mathrm{C}_{29}\right)$ are represented by $\alpha$-sterans and iso-sterans. Based on the main geochemical criteria the degree of catagenesis of oils and the probability of biodegradation of some of them was determined. In some crude oils polymethylsubstituted decalines, the relict type hydrocarbons $\left(\mathrm{C}_{14}-\mathrm{C}_{16}\right)$ have been identified.
\end{abstract}

Citation: Natela Khetsuriani, Vladimer Tsitsishvili, Elza Topuria, Madlena Chkhaidze, Irina Mchedlishvili. (2020) Chemical Typification and Genetic Criteria for the Composition of Georgian Petroleum. World Science. 5(57), Vol.1. doi: 10.31435/rsglobal_ws/31052020/7074

Copyright: (C) 2020 Natela Khetsuriani, Vladimer Tsitsishvili, Elza Topuria, Madlena Chkhaidze, Irina Mchedlishvili. This is an open-access article distributed under the terms of the Creative Commons Attribution License (CC BY). The use, distribution or reproduction in other forums is permitted, provided the original author(s) or licensor are credited and that the original publication in this journal is cited, in accordance with accepted academic practice. No use, distribution or reproduction is permitted which does not comply with these terms.

Introduction. Organic geochemistry is a scientific direction in chemistry of natural biological compounds, the main task of which is study of composition and chemical evolution of organic molecules in sedimentary rocks [1]. These fossil molecules, chemofossils (relict hydrocarbons) of plant and animal origin, after being deposited in rocks, remained almost unchanged. They are unique as they preserved identity or underwent insignificant change in composition and structure of the carbon skeleton of the 
original biological molecules that took part in the processes of oil formation [2]. These relicts are considered as the most important biomarkers or geochemical labels that are used in understanding of biological conditions and many problems of oil genesis. Any regularity in their distribution in samples is geochemical criterion and allows to understand the nature and origin of the source of raw material, its age, degree of decomposition and catagenetic maturity. This information is used to carry out various geochemical correlations, genetic and chemical typifications of oils and to solve various problems of petroleum geochemistry [3]. The composition and molecular-mass distribution of chemofossils in oils determine the genetic type of oils. In contrast to the genetic type, the chemical type (composition) is changed with time under the impact of thermobaric, catalytic factors, water-oil contact and postgenetically changes of oils (biodegradation and migration) [4]. The role of hemofossils in perception of oils in general is invaluable. The most important biomarkers are normal and isoprenoid alkanes, cyclic hydrocarbons with one to five cycles per molecule, $\mathrm{C}_{19}-\mathrm{C}_{35}$ sterane and terpane hydrocarbons, sesqui-, diand triterpane series, terpenes, steroids, porphyrins and relatively little-studied aromatic hydrocarbons with relict type structure [5]. Currently, more than 1000 different biomarkers have been identified in oils and organic matter of rocks. Among them, new representatives of the hemofossils, characteristic of the most ancient organisms belonging to the natural habitat of Bacteria, Archaea, Eucarya, have been discovered [6]. Biomarkers along with isotopic composition of carbon are the main source of information about the bios during the ancient periods of the Earth [7].

In this article are presented the results of the study of molecular composition of relict hydrocarbons of some Georgian crude oils, are considered genetic and geochemical aspects of their chemical composition, the main geochemical criteria that give a possibility to make various genetic correlations.

Purpose of the study: chemical and genetic type of Georgian Petroleum.

Materials and methods. All used chemicals were of analytical grade. The HPLC/GC grade methanol, n-pentane, benzene, and petroleum ether were purchased from Sigma-Aldrich and Merck (Germany) companies. Activated fine silica gel $(0.07-0.15$ and $0.2-0.3 \mathrm{~mm}$ ) was supplied by Labstatus (Ukraine) and ChemReactiveSnab (Almaty, Kazakhstan) companies. The coarse silica gel (0.4-2.5 mm) was supplied by Salavat catalyst plant (Russia). Carbamide- CaS Number 57-13-6; Beilstein Number 635724; Sigma-Aldrich (Germany) and thiourea - from Biochem (France). Carrier gas - hydrogen (CB Index: 87; Product Catalog: 9628, Customer Evaluation: 6, CAS: 1333-74-0; Remarks: Brand: SigmaAldrich / Product Number: 295396 / Purity: $\geq 99.99 \%)$. Apiezon L Ultra High Vacuum Grease, Silicone \& Halogen Free, CAS \#8009-03-8 were supplied by Sigma-Aldrich (Germany).

The following methods were used for the study: distillation, liquid adsorption chromatography, gas-liquid chromatography; deparaffinization by carbamide; three stage thermal diffusion; extraction by thiocarbamide, mass spectrometry and chromatography-mass spectrometry.

The gas-liquid chromatographic separation of the studied fractions was carried out on capillary columns in the following conditions: the fraction $50-200^{\circ} \mathrm{C}$ (column $100 \mathrm{~m} \times 0.25 \mathrm{~mm}$, linear programming of temperature from 50 to $200^{\circ} \mathrm{C}$ with a speed of $2^{\circ} \mathrm{C} / \mathrm{min}$ ); the fraction $200-350^{\circ} \mathrm{C}$, the VIII fraction of thermodiffusion separation (column $200 \mathrm{~m} \times 0.25 \mathrm{~mm}$ with dimethylpolysiloxane, liner programming of temperature from $40^{\circ} \mathrm{C}$ to $280^{\circ} \mathrm{C}$ with a speed of $2^{\circ} \mathrm{C} / \mathrm{min}$, hold $70 \mathrm{~min}$ ) and filtrates of the thiourea adducts with the mixture of IX+X thermal diffusion fractions (column $50 \mathrm{~m} \times$ $0.25 \mathrm{~mm}$, linear programming of temperature - from $100^{\circ} \mathrm{C}$ to $280^{\circ} \mathrm{C}$ with a speed of $2^{\circ} \mathrm{C} / \mathrm{min}$ ); fractions $200-420^{\circ} \mathrm{C}$ (column $100 \mathrm{~m} \times 0.25 \mathrm{~mm}, 50$ thousands of theoretical plates, linear programming of temperature - from $100^{\circ} \mathrm{C}$ to $320^{\circ} \mathrm{C}$ with a speed of $2^{\circ} \mathrm{C} / \mathrm{min}$ ); the fraction $>420^{\circ} \mathrm{C}$ - the same column, temperature of thermostat $290^{\circ} \mathrm{C}$; liquid phase - Apiezon L.

Chromatography-mass spectrometry analysis was performed on the LKB-2091 instrument. The ion source temperature was $50^{\circ} \mathrm{C}$ and the ionization potential was $70 \mathrm{eV}$. Stainless steel column $40 \times 0.4 \mathrm{~mm} ; 50$ thousands of theoretical plates; programmed temperature according to samples.

\section{Experimental part.}

For the study of molecular composition of relict hydrocarbons, samples of crude oils from the main oil and gas regions of Eastern Georgia - Samgori, Teleti, Shromis-Ubani, Norio, Ninotsminda, Mirzaani, Taribani, Satskhenisi [8] were studied. These oils belong to a single sedimentation basin, are of different chemical type, have close geological age of the host rocks and a different depth of bedding.

The objects of the investigation were saturated hydrocarbons of fractions $50-200^{\circ} \mathrm{C}, 200$ $350^{\circ} \mathrm{C}, 200-420^{\circ} \mathrm{C}$ and $>420^{\circ} \mathrm{C}$, that were dearomatized on activated fine and coarse silica gel; fractions $200-350^{\circ} \mathrm{C}$ and $>420^{\circ} \mathrm{C}$ were as well deparaffinazed by conventional method; the components of composition was studied by GLC. 
In the light fractions $\left(50-200^{\circ} \mathrm{C}\right)$ of the studied oils, over 100 individual hydrocarbons of $\mathrm{C}_{5-}$ $\mathrm{C}_{11}$ composition were identified. Interesting regularities were found in the composition of cyclopentanes and cyclohexanes; in addition, when studying distribution of isomeric nonanes and decanes the highest levels of 2,3- and 2,6-dimethylalkanes, as well as of 2-methyl-3-ethylheptane, the main relicts of light fractions of oils, were found.

Chromatogram of the thermodiffusion fraction VIII (the $200-350^{\circ} \mathrm{C}$ fraction of Taribani oil) is shown in Figure 1. Complex study of MS data and GC retention indices made it possible to divide isomers, which in itself is a great difficulty in the process of compounds identification. The main components of the VIII thermodiffusion fraction, as it was expected, are $\mathrm{C}_{11}-\mathrm{C}_{22}$ isoprenoid alkanes. Among them the predominant are 2,6,10,14-tetramethylpentadecane (pristane, $\mathrm{C}_{19} \mathrm{H}_{40}$ ) and 2,6,10,14-tetramethylhexadecane (phytane, $\mathrm{C}_{20} \mathrm{H}_{42}$ ), the well-known biomarkers of oil. Cyclopentanes, cyclohexanes and decalines having retention times from 89 to 95 minutes (Figure 1) were characterized by low intensity.

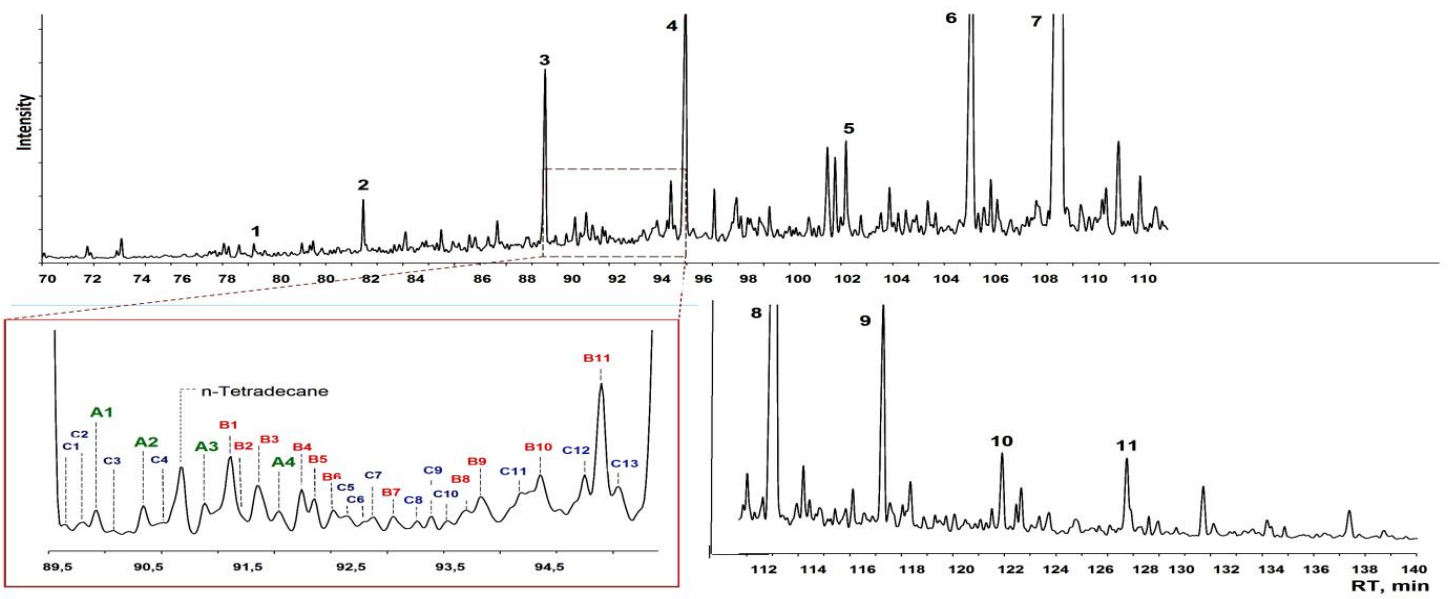

Fig. 1. GC of concentrate VIII obtained after thermal diffusion: Isoprenoides: 1-Undecane 2,6dimethyl-(C13); 2 -Dodecane 2,6-dimethyl-(C14); 3-Dodecane, 2,6,10-trimethyl-(C15); 4-Tridecane 2,6,9trimethyl-(C16); 5-Tetredecane 2,6,10-trimethyl-(C17); 6-Pentadecane 2,6,10-trimethyl-(C18); 7 -Pristan-(C19); 8 - Pristan-(C20); 9 -Heptadecane 2,6,10,15-tetramethyl-(C21); 10 - Octadecane 2,6,10,15-tetramethyl-(C22); 11 - Nonadecane 2,6,10,15-tetramethyl-(C23).

Among bicycloalkanes the content of the relict-type structures - the long-chain derivative of perhydroindan - 1-(2-methyl, hexyl)-perhydroindan and polymethyl derivatives of decalin - were determined. Typical structures and corresponding mass-spectra are presented on Figure 2. [9].

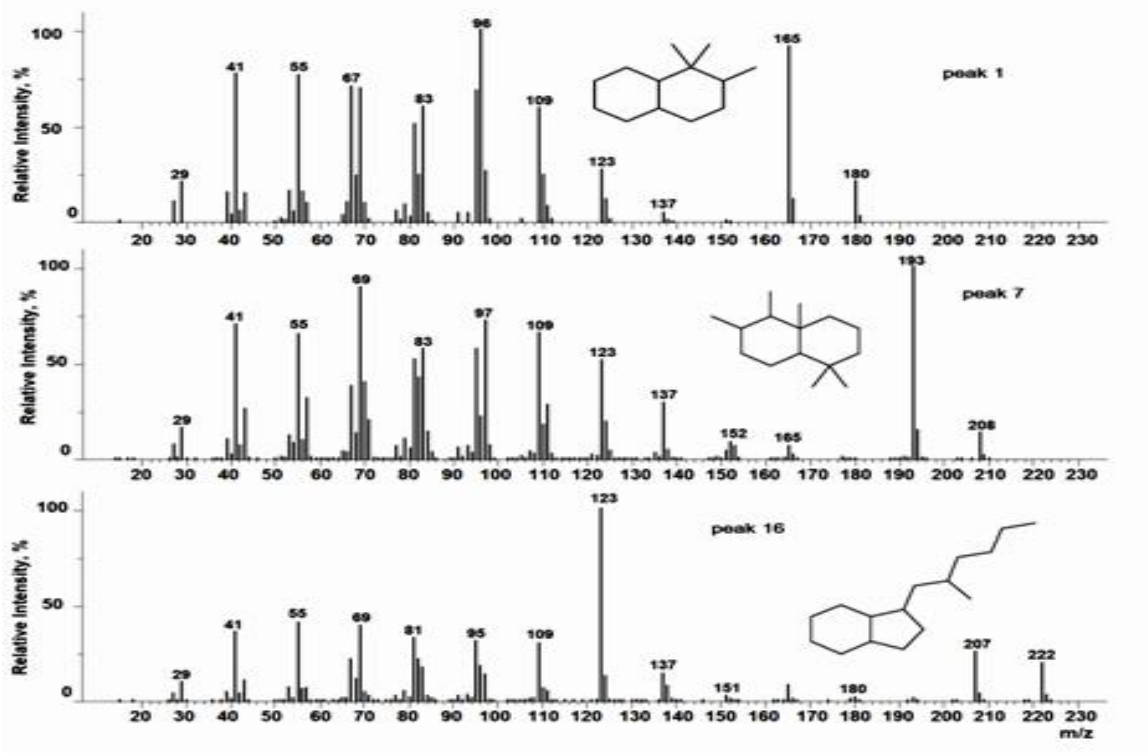

Fig. 2. Mass spectra of (c) 1,1,2-Trimethyldecaline (peak 1), 1,2,3,7,7-Pentamethyldecaline (peak 7) and 1-(2-Methylhexyl)perhydroindane (peak 16). 
Based on the study of relative distribution of the main relict hydrocarbons - normal $\mathrm{C}_{12}-\mathrm{C}_{32}$ and isoprenoid $\mathrm{C}_{14}-\mathrm{C}_{22}$ alkanes in middle fractions boiling away at a temperature of $200-420^{\circ} \mathrm{C}$, "the chemical typification" of oils was carried out on highly efficient capillary columns according to the method of prof. Al.A. Petrov [10]. From the chromatograms for all the above listed oils the mentioned above ratios were calculated and the corresponding diagrams were plotted. Relative distribution of normal and isoprenoid alkanes in oils of the type opposite to Taribani $\mathrm{A}^{1}$ and Satskhenisi $\mathrm{B}^{2}$ oils is shown on Figures 1 and 2[11]. Based on the diagrams, the geochemical isoprenoid coefficients $\mathrm{Ki}=$ $\Sigma \mathrm{iC}_{19}-\mathrm{iC}_{20} / \Sigma \mathrm{nC}_{17}-\mathrm{nC}_{18}$ and catagenetic coefficients $\mathrm{K}=\Sigma \mathrm{nC}_{13}-\mathrm{nC}_{15} / \Sigma \mathrm{nC}_{25}-\mathrm{nC}_{27}$ ), the values of which are related to the biodegradation and catagenetic transformation of oils, as well as geochemical criteria - the ratio of pristane to phytane $\mathrm{iC}_{19} / \mathrm{iC}_{20}$, which are used to carry out various geochemical correlations are determined. On the basis of these characteristics the studied oils are confined to various chemical types: Samgori- $\mathrm{A}^{1}$, Ninotsminda- $\mathrm{A}^{1}$, Shromis-Ubani- $\mathrm{A}^{2}$, Mirzaani-B ${ }^{2}$, Norio-B ${ }^{1}$, Teleti-B ${ }^{1}$, Taribani- $\mathrm{A}^{1}$, Satskhenisi-B ${ }^{2}$. Oils of $\mathrm{A}^{1}$ type by group composition correspond to paraffin oils; $\mathrm{B}^{2}$ oil - to naphthenic oils. The oils of $\mathrm{A}^{2}$ and $\mathrm{B}^{1}$ types have intermediate characteristics of chemical composition. The study of the individual composition of oils showed that normal alkanes were present in large quantities in oils of A type. But a characteristic feature of all types of Georgian oils is high concentration of isoprenoid structures, especially of regular isoprenoids $\left(\mathrm{iC}_{19}\right.$ and $\left.\mathrm{iC}_{20}\right)$, moreover, with a large predominance of pristine. Relative distribution of normal and isoprenoid alkanes in $200-420^{\circ} \mathrm{C}$ fraction of Taribani and Satskhenisi oils are shown in Figures 3 and 4. Therefore, for almost all oils, the ratio $\mathrm{iC}_{19} / \mathrm{iC}_{20}$ is higher than 1 . This indicator $\left(\mathrm{iC}_{19} / \mathrm{iC}_{20}>1\right)$ is an important geochemical characteristic associated both with the origin and with transformation of oil during the processes of biodegradation and catagenesis [12]. Norio oil is an exception: $\mathrm{iC}_{19}$ and $\mathrm{iC}_{20}$ are completely absent in it, and $\mathrm{iC}_{14}$ and $\mathrm{iC}_{16}$ are present in high concentrations. Characteristics of the studied oils are given in table 1.

Table 1. Characteristics of Georgian Petroleums

\begin{tabular}{|l|c|c|c|c|c|c|c|}
\hline $\begin{array}{c}\text { Name of the } \\
\text { Crude oil, } \\
\text { well No. }\end{array}$ & $\begin{array}{c}\text { Depth of } \\
\text { Bedding, } \\
\mathrm{m}\end{array}$ & $\begin{array}{c}\text { Age of } \\
\text { the } \\
\text { enclosed } \\
\text { rocks }\end{array}$ & $\begin{array}{c}\text { Density } \\
\left(\mathrm{kg} / \mathrm{m}^{3}\right)\end{array}$ & $\begin{array}{c}\text { Tars and } \\
\text { asphaltenes, } \\
\%\end{array}$ & $\mathrm{~S}, \%$ & $\begin{array}{c}\text { Chemical } \\
\text { type }\end{array}$ & $\begin{array}{c}\text { Genetic } \\
\text { mark } \\
\mathrm{iC}_{19} / \mathrm{iC}_{20}\end{array}$ \\
\hline Samgori,.7 & 2800 & $\begin{array}{c}\text { Middle } \\
\text { Eocene }\end{array}$ & 886.0 & 18.2 & 0.25 & $\mathrm{~A}^{1}$ & 2.2 \\
\hline Ninotsminda,.27 & 2800 & $\begin{array}{c}\text { Middle } \\
\text { Eocene }\end{array}$ & 892.0 & 18.5 & 0.23 & $\mathrm{~A}^{1}$ & 2.2 \\
\hline $\begin{array}{l}\text { Shromis-Ubani, } \\
1\end{array}$ & 3000 & $\begin{array}{c}\text { Late } \\
\text { Miocene }\end{array}$ & 927.0 & 32.9 & 0.37 & $\mathrm{~A}^{2}$ & 1.6 \\
\hline Norio, 35 & 1400 & $\begin{array}{c}\text { Middle } \\
\text { Sarmat }\end{array}$ & 924.0 & 21.5 & 0.15 & $\mathrm{~B}^{1}$ & 1.9 \\
\hline Teleti, 18 & 2374 & $\begin{array}{c}\text { Middle } \\
\text { Eocene }\end{array}$ & 876.0 & 18.4 & 0.18 & $\mathrm{~B}^{1}$ & 1.7 \\
\hline Mirzaani, 109 & $\begin{array}{c}\text { Lower } \\
\text { Pliocene }\end{array}$ & $\begin{array}{c}\text { Late } \\
\text { Sarmat }\end{array}$ & 838.6 & 14.84 & 0.25 & $\mathrm{~A}^{1}$ & 1.7 \\
\hline Taribani, 23 & 1400 & $\begin{array}{c}\text { Late } \\
\text { Oligocene }\end{array}$ & 836.1 & 32.68 & 0.26 & $\mathrm{~B}^{2}$ & 2.2 \\
\hline Satskhenisi, 4 & & & 14,72 & 0.22 & $\mathrm{~B}^{2}$ & 0.3 \\
\hline
\end{tabular}

By the method of mass spectrometry for the hydrocarbons in the paraffin-cycloparaffin part of all studied oils, the structural group composition of the middle $\left(200-420^{\circ} \mathrm{C}\right)$ fractions - the relative distribution of alkanes and mono-, bi-, tri-, tetra- and pentacyclic naphthenic hydrocarbons, inherited by oils from the original organic matter, was determined. From the geochemical point of view, this characteristic is one of the genetic characteristics, which indicates both the distribution of naphthenic hydrocarbons and the single genetic type of Georgian oils (the so-called "naphthenic passport"). This characteristic shows that the cyclic compounds in various Georgian oils are represented in high concentrations. 


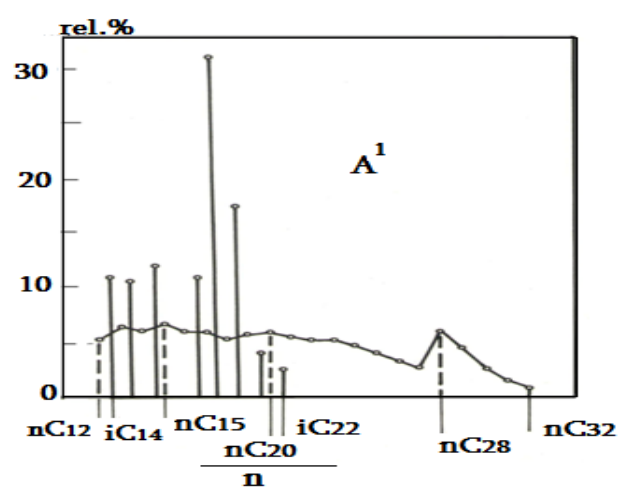

Fig. 3. Relative distribution of normal $\left(C_{12}-C_{32}\right)$ and isoprenoid $\left(C_{14}-C_{22}\right)$ alkanes in the fraction $200-$ $420^{\circ} \mathrm{C}$ of Taribani oil.

$n-$ number of carbon atoms in alkanes

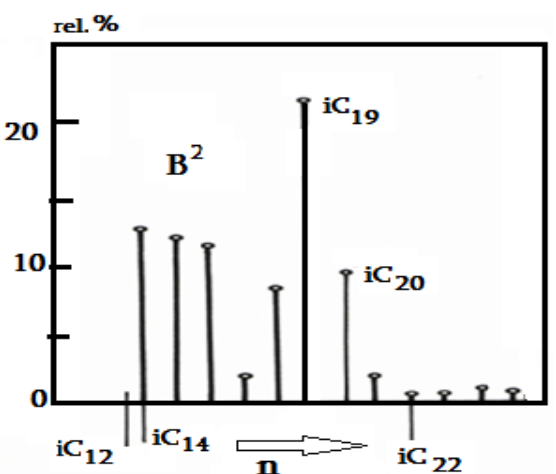

Fig. 4. Relative distribution of isoprenoid $\left(C_{14}-C_{22}\right)$ alkanes in the fraction $200-420^{\circ} \mathrm{C}$ of Satskhenisi oil $n$-number of carbon atoms in alkanes

Fractions $200-350^{\circ} \mathrm{C}$ and $>420^{\circ} \mathrm{C}$ that contained mainly polycycloalcanes were subjected to thermal diffusion with the aim of separation of concentrates from them. By using of thermal diffusion method with selection of optimal conditions (temperature gradient, separation time) and column efficiency it becomes possible to extract successfully concentrates of different hydrocarbons from oil fractions. In this study large and micro-TDF columns were used. The height of the large columns was $1500 \mathrm{~cm}$, the volume of the annular space $-50 \mathrm{ml}$, the clearance $-0.3 \mathrm{~mm}$ with a coil in the working space. Stainless steel microcolomns of the original design had a volume of 3, 4 and $4.5 \mathrm{ml}$. These columns are of the Melpolder's columns type, their efficiency factor in dividing the model mixture of cis- and trans-decalines $(1: 1)$ is maximum $\mathrm{S}=99 \%$ in $8-10$ hours. Their height is $110 \mathrm{~mm}$. These columns were designed and manufactured at the Petre Melikishvili Institute of Physical and Organic Chemistry, Laboratory of Petroleum Chemistry [13]. The columns have 10 drain cocks that provide separation of mixtures into ten equal-volume fractions. For extraction of naphthenic concentrates, saturated fractions of $200-350^{\circ} \mathrm{C}$ and $>420^{\circ} \mathrm{C}$ were subjected to two-fold thermal diffusion (temperature gradient $130^{\circ} \mathrm{C}-150^{\circ} \mathrm{C}$, separation time -100 hours). At the end of the process a mixture of fractions $(\mathrm{IX}+\mathrm{X})$ - naphthenic concentrates was taken [14].

According to data of MS analysis in concentrates of fraction $200-350^{\circ} \mathrm{C}$ mainly $(\sim 90 \%)$ tri-, tetra- and pentacycloalkanes of compact structure and bicycloalkanes of $\mathrm{C}_{14}-\mathrm{C}_{16}$ composition were present. Concentrates, obtained from the $200-350^{\circ} \mathrm{C}$ fraction in order to hydrocarbons that form adducts were treated with thiocarbamide (conditions: thiocarbamide: fraction $=1: 1$; activator-methanol; diluentbenzene; time $25 \mathrm{~h}$; temperature $6^{\circ} \mathrm{C}$ ) [15]. In the residual filtrates of concentrates from Taribani, Satskhenisi, Norio and Teleti oils the relict bicycloalkanes - the polymethylsubstituted decalines of $\mathrm{C}_{14}$ $\mathrm{C}_{16}$ composition were identified. Hydrocarbons (1-6) were determined in Taribani, $(2,3,6)$ in Satskhenisi and $(2,4)$ in Norio and Teleti oils [16]. On chromatograms of the filtrates (Fig.5) peaks corresponding to the said hydrocarbons are marked with numbers 1' -6 ' (for Taribani oil) and 1-3 (for Satskhenisi oil). Composition and structure of the said hydrocarbons is determined by chromatographymass spectrometry analysis. The characteristic peaks of mass-spectrometric destruction, the assumed structures and gross formulas of the identified polymethylsubstituted decalines are presented in Table 2 .
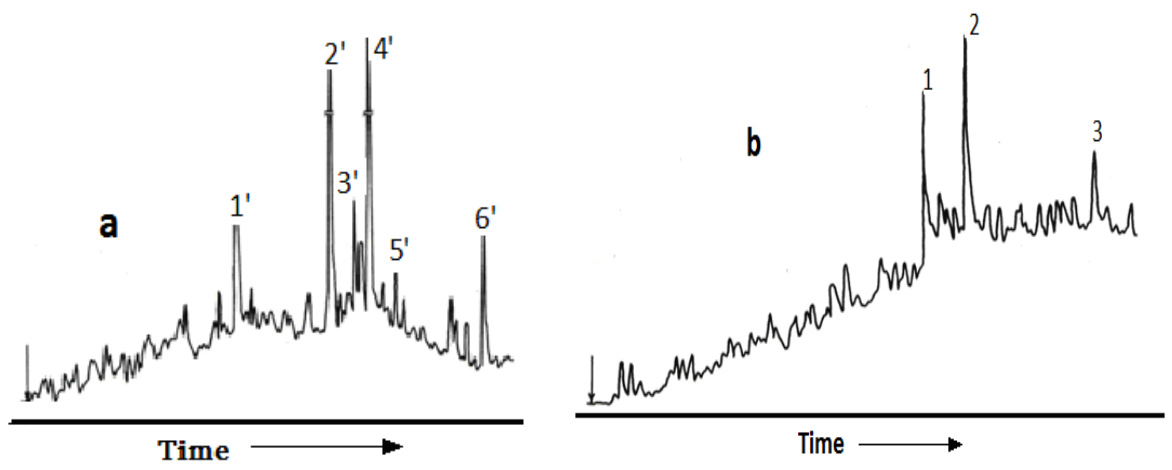

Fig. 5. Chromatogram of bicycloalkanes from the $200-350{ }^{\circ} \mathrm{C}$ fractions (a) of Taribani and (b) Satskhenisi Crude Oils 
Table 2. Polymethylsubstituted decalines, identified in Georgian Petroleum

\begin{tabular}{|c|c|c|c|c|c|c|}
\hline \multicolumn{4}{|c|}{$\begin{array}{l}\text { \# of hydrocarbon } \\
\text { In samples }\end{array}$} & \multirow[t]{2}{*}{$\begin{array}{c}\text { Name of } \\
\text { Hydrocarbon }\end{array}$} & \multirow[t]{2}{*}{$\begin{array}{l}\text { Structural and } \\
\text { brutto-formula }\end{array}$} & \multirow{2}{*}{$\begin{array}{c}\text { Characteristic peaks in mass-spectra } \\
\text { (intensity in } \% \text { of the maximum peak) } \mathrm{m} / \mathrm{z} \\
\text { (I, rel \%) }\end{array}$} \\
\hline I & II & III & IV & & & \\
\hline 1 & - & - & - & $\begin{array}{l}\text { cis- } 1,3,7,7- \\
\text { tetramethyl- } \\
\text { trans-bicyclo- } \\
/ 4,4,0 / \text { decane }\end{array}$ & & $\begin{array}{l}194\left(\mathrm{M}^{+} ; 21\right), \quad 180(8), \quad 179(72), 138(7), \\
137(16), \quad 122(18), \quad 121(68), \quad 110(45), \\
109(69), 97(37), 96(23), 95(75), 83(43), \\
82(32), 81(100), 69(72), 55(40)\end{array}$ \\
\hline 2 & 2 & 2 & 2 & $\begin{array}{l}\text { trans-2,3,3,7 } \\
\text { 7-pentamethyl- } \\
\text { trans-bicyclo- } \\
/ 4,4,0 / \text { decane }\end{array}$ & & 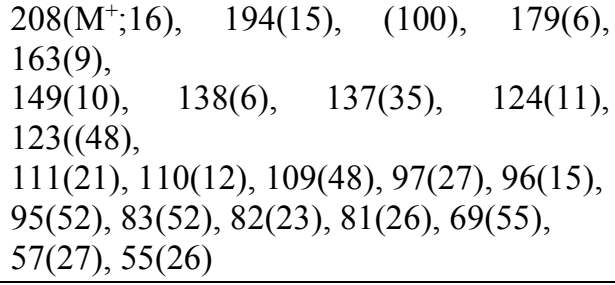 \\
\hline 3 & 3 & - & - & $\begin{array}{l}1,3,3,7,7- \\
\text { pentamethyl- } \\
\text { trans-bicyclo/4,4,0/- } \\
\text { decane }\end{array}$ & & 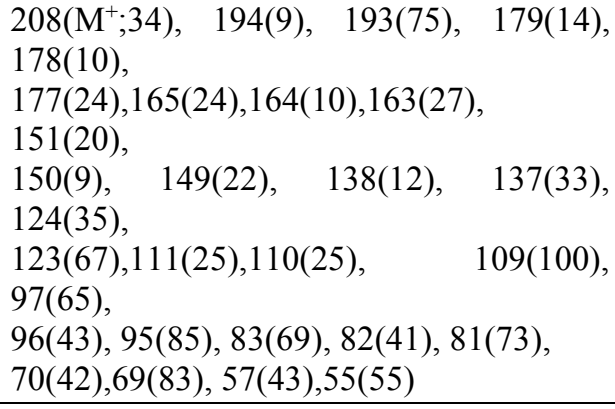 \\
\hline 4 & - & 4 & 4 & $\begin{array}{l}\text { cis- } 2,2,3,7,7- \\
\text { pentamethyl- } \\
\text { trans-bicyclo- } \\
/ 4,4,0 / \text { decane }\end{array}$ & & $\begin{array}{l}208\left(\mathrm{M}^{+} ; 20\right), 194(7), 193(100), 179(6), \\
177(7), \\
165(11), 163(6), 151(9), 150(9), 149(25), \\
137(32), 135(12), 124(25), 123(49), \\
149(51), \\
97(31), 96(25), 95(85), 83(31), 82(29), \\
81(61), \\
70(71), 69(65), 68(13), 67(26), 58(26), \\
57(29), 55(36)\end{array}$ \\
\hline 5 & - & - & - & $\begin{array}{l}\text { trans-cis- } 1,2,3, \\
7,7 \text {-pentamethyl- } \\
\text { trans-bicyclo } \\
/ 4,4,0 / \text { decane }\end{array}$ & & $\begin{array}{l}208\left(\mathrm{M}^{+} ; 27\right), \quad 194(6), 193(41), 165(4), \\
139(2), \\
138(13), \quad 137((32), 124(17), 123(100), \\
109(26), \\
97(7), 96(4), 95(35), 83(9), 82(11), 81(27), \\
79(2), 69(25), 68(4), 67(16), 57(8), 55(22)\end{array}$ \\
\hline 6 & 6 & - & - & $\begin{array}{l}\text { 1,3,7,7-tetramethyl- } \\
\text { 2-ethyl- trans- } \\
\text { bicyclo } \\
/ 4,4,0 / \text { decane }\end{array}$ & & $\begin{array}{llll}222\left(\mathrm{M}^{+} ; 37\right), & 207(15), & 194(5), & 193(56), \\
177(10), \quad 138(20), & 137(37), & 124(21), \\
123(100), \quad 111(8), & 110(14), & 109(63), \\
97(18), 96(13), 95(58), & & \\
83(25), 82(6), & 81(58), & 69(51), & 70(12), \\
67(26), & & & \\
57(25), 55(40) & & \end{array}$ \\
\hline
\end{tabular}

${ }^{a}$ Oils from I - Taribani, II - Satskhenisi, III - Norio, IV - Teleti deposits.

From the geochemical point of view large molecules of relict type saturated hydrocarbons tetra- and pentacyclic naphthenes, namely steranes and triterpanes, the predecessors of which are considered to be natural steroids and triterpenoids found in various geological objects are of particular interest [17]. Steranes and triterpanes of the saturated hydrocarbon fractions of Georgian oils Norio, Teleti, Mirzaani, Sartichala, Ninotsmindai, Shromis-Ubani, boiling away above $420^{\circ} \mathrm{C}$ have been studied [18]. Saturated hydrocarbons were separated from oil fractions residues by chromatography on 
ASK silica gel. In case of paraffinic oils the normal alkanes were removed by treatment with thiourea. Concentration of tetra- and pentacycloalkanes was carried out by the method of thermodiffusion. Analysis of concentrates and qualitative identification of the main gas-chromatografic peaks was carried out by gas-liquid chromatography and chromatography-mass-spectrometry methods. The results of the studies are presented in Tables 3 and 4 .

Table 3. Relative concentration of $17 \alpha \mathrm{H}$-hopane series hydrocarbons of Georgian oils in fraction with boiling point $>420^{\circ} \mathrm{C}$

\begin{tabular}{|c|c|c|c|c|c|c|c|}
\hline \multirow[b]{2}{*}{ Grude Oil deposit } & \multicolumn{6}{|c|}{ Number of carbon atoms } & \multirow{2}{*}{$\begin{array}{c}\Sigma \text { hopanes, } \\
\text { in mass \% } \\
\text { (per oil) }\end{array}$} \\
\hline & 27 & 29 & 30 & 31 & 32 & 33 & \\
\hline Norio & 2,5 & 11,0 & 31,2 & 25,8 & 16,7 & 12,8 & 0,60 \\
\hline Teleti & 6,6 & 10,3 & 35,9 & 21,7 & 14,5 & 11,0 & 0,20 \\
\hline Mirzaani & 8,2 & 12,7 & 30,6 & 22,7 & 18,4 & 7,4 & 0,20 \\
\hline Samgori & 7.7 & 12,3 & 33,3 & 23,3 & 13,6 & 9,8 & 0,40 \\
\hline Ninotsminda & 7,9 & 9,7 & 26,7 & 22,1 & 17,2 & 16,4 & 0,35 \\
\hline Shromis-Ubani & 1,8 & 14,7 & 32,1 & 26,2 & 14,2 & 11,0 & 0,10 \\
\hline
\end{tabular}

Table 4. Relative concentration of sterane hydrocarbons in fraction with boiling point $>420^{\circ} \mathrm{C}$

\begin{tabular}{|c|c|c|c|c|c|c|c|c|c|c|c|c|}
\hline \multirow[b]{2}{*}{$\begin{array}{c}\text { Crude oil } \\
\text { Deposit }\end{array}$} & \multicolumn{3}{|c|}{ Cholestanes $\mathrm{C}_{27}$} & \multicolumn{3}{|c|}{ Ergostanes $\mathrm{C}_{26}$} & \multicolumn{4}{|c|}{ Sitostanes $\mathrm{C}_{29}$} & \multirow[b]{2}{*}{ 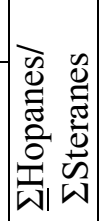 } & \multirow[b]{2}{*}{ 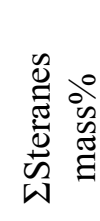 } \\
\hline & iso & $\alpha$ & $\sum$ iso $+\alpha$ & iso & $\alpha$ & Eiso $+\alpha$ & iso & $\alpha$ & Liso $+\alpha$ & $\alpha /$ iso & & \\
\hline Norio & 21,2 & 6,6 & 27,8 & 26,9 & 14,5 & 41,4 & 24,9 & 5,9 & 30,8 & 0,24 & 2,3 & 0,30 \\
\hline Teleti & 27,6 & 6,9 & 34,5 & 23,6 & 10,6 & 34,2 & 23,7 & 7,6 & 31,3 & 0,32 & 1,1 & 0,20 \\
\hline Mirzaani & 28,2 & 7,2 & 35,4 & 36,5 & 6,4 & 42,9 & 17,6 & 4,1 & 21,7 & 0,23 & 0,8 & 0,25 \\
\hline Samgori & 35,1 & 5,7 & 40,8 & 26,9 & 6,2 & 33,1 & 20,4 & 5,7 & 26,1 & 0,28 & 1,1 & 0,40 \\
\hline Ninotsminda & 28,7 & 7,3 & 36,0 & 25,9 & 10,8 & 36,7 & 17,7 & 9,6 & 27,3 & 0,54 & 1,2 & 0,30 \\
\hline $\begin{array}{l}\text { Shromis- } \\
\text { Ubani }\end{array}$ & 21,1 & 9,8 & 30,9 & 25,5 & 11,1 & 36,6 & 20,3 & 12,2 & 32,5 & 0,60 & 2,8 & 0,03 \\
\hline
\end{tabular}

The research results. The structure of polymethylsubstituted decalines from fractions 200$350^{\circ} \mathrm{C}$ is determined by chromatography-mass spectrometric degradation method according to their characteristic peaks. When determining the location of the alkyl substituent it was taken into account that the presence of two geminal $\mathrm{CH}_{3}$ groups led to a sharp increase of $/ \mathrm{M}-15 /^{+}$ion peak intensity in the mass spectra in contrast to the simultaneous presence of geminal and angular groups. In spectra corresponding to hydrocarbons 2, 3 and 4 (Table 2), there are low-intensity peaks of molecular ions

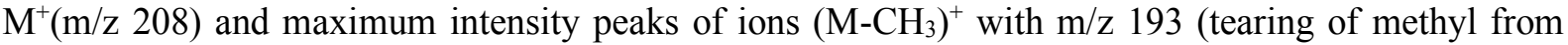
molecular ion). At the same time, there are no fragments with a mass corresponding to tearing of the ethyl- $\left(\mathrm{M}^{+}-29\right)$ and propyl- or isopropyl group $\left(\mathrm{M}^{+}-43\right)$. The hydrocarbons under study are bicycloalkanes with many methyl groups. In hydrocarbons $(1,5,6)$ with one geminal group, the peaks of $\mathrm{M}^{+}$ions are insignificant. Hydrocarbons $(2,3,4)$ were attributed the structure of the sesquiterpane type, the composition of $\mathrm{C}_{15} \mathrm{H}_{28}$ [19], and hydrocarbons $(1,5,6)-$ of polymethyl-substituted transdecalines. The peculiarity of the structure of these hydrocarbons indicates the generality of their genesis [20]. They have a clearly relict character and most probably are genetically associated with important relicts - the hopanes [21].

The results of the study of relative distribution of the main biomarkers of oils - steranes and hopanes, make it possible to establish that the studied crude oils belong mainly to the $17 \alpha \mathrm{H}$-hopane series [22]; the yield of the sum of hopanes per oil is from 0.1 to $0.6 \%$, and the sum of steranes - from 0.03 to $0.4 \%$. At the same time, $17 \alpha \mathrm{H}$-hopane itself $\left(\mathrm{C}_{30} \mathrm{H}_{52}\right)$ is present in maximum concentration. 
Triterpanes $\left(\mathrm{C}_{27}-\mathrm{C}_{33}\right)$ are represented mainly by hopane homologues. Steranes $\left(\mathrm{C}_{27}-\mathrm{C}_{29}\right)$ in crude oils are represented by $\alpha$-sterananes and isosteranes. They are characterized by cis-coupling of $\mathrm{C} / \mathrm{D}$ cycles and constitute the main mass of steranes. Mirzaani oil is an exception. There is predominance of sterane structures. The distribution of steranes and hopanes make it possible to determine important geochemical parameters that carry genetic information about the degree of catagenetic conversion of oils, the chemical composition of the oil-producing biomass, etc. [23]. Based on the studied relicts, various genetic correlations were carried out [24]. It was established that despite the difference in chemical composition of oils they belong to a single genetic type in terms of geochemical parameters the ratio of the main relict hydrocarbons: pristan/phytan (iso- $\mathrm{C}_{19} /$ iso- $_{20}$ ), $\sum$ hopanes/ $\sum$ steranes (Tables $1,3,4)$, as well as distribution of $\mathrm{n}$-, iso- and cycloparaffin hydrocarbons in fractions $200-420^{\circ} \mathrm{C}$ ("naphthenic passport"). To reveal catagenetic maturity of oils, other indicators were calculated, for example: concentrations of secondary steranes of $\mathrm{C}_{27}$ composition, ratio $\alpha$-steranes/iso-steranes, etc. The highest degree of catagenesis was determined for Samgori oil, and the lowest one - for oil from the Shromis-Ubani deposit. The possibility of probable biological degradation of some of these oils in pools is assumed. Although, their different chemical composition may be stipulated to different conditions of bedding and biological oxidation. Formation of $\mathrm{B}^{1}$ and $\mathrm{B}^{2}$ type oils - Teleti, Norio, Mirzaani, Satskhenisi and Shromis-Ubani $\left(\mathrm{A}^{2}\right)$ - is based on biological oxidation. High concentrations of n-alkanes, isoprenodic alkanes and monocyclic naphthenes in oils of the primary generation $\mathrm{A}^{1}-$ Samgori, Ninotsminda, Taribani - indicate that they almost did not undergo biodegradation. Biological oxidation probably affects only normal alkanes, leaving isoprenanes unchanged. The data of biological conditions in the oil pools explain the characteristic feature of all types of Georgian oils the presence of high concentrations of isoprenoid alkanes in them.

\section{Conclusions.}

1. Appliance of Georgian oils to different chemical types was determined: Norio, Teleti $-\mathrm{B}^{1}$; Mirzaani, Satskhenisi - B ${ }^{2}$; Samgori, Ninotsminda, Taribani $-A^{1}$, Shromis-Ubani $-A^{2}$. It was established that despite the differences in chemical composition the studied oils were genetically similar by ratios $\mathrm{iC}_{19} / \mathrm{iC}_{20}$, $\Sigma$ hopanes/ $\Sigma$ steranes, as well as by "naphthenic passport". The characteristic feature of Georgian oils is revealed - high concentrations of isoprenoid alkanes, pristane $\left(\mathrm{iC}_{19}\right)$ and phytane $\left(\mathrm{iC}_{20}\right)$ with high predominance of pristane so the ratio $\mathrm{iC}_{19} / \mathrm{iC}_{20}>1$.

2. Polymethylsubstituted decalines, a relict type hydrocarbons the so-called sesquiterpane hydrocarbons of $\mathrm{C}_{14}-\mathrm{C}_{16}$ composition have been identified in the middle fractions of Taribani, Satskhenisi, Norio and Teleti oils.

3. In high-boiling fractions $>420^{\circ} \mathrm{C}$, big tetra- and pentacycloalkane molecules $\left(\mathrm{C}_{27}-\mathrm{C}_{33}\right)-$ steranes and triterpanes with the predominance of hopanes belonging to the $17 \alpha \mathrm{H}$-hopan $\left(\mathrm{C}_{30} \mathrm{H}_{52}\right)$ series have been identified. Hopane itself as $17 \alpha \mathrm{H}$-hopane is present in maximum concentration. It has been shown that oil steranes $\left(\mathrm{C}_{27}-\mathrm{C}_{29}\right)$ were represented by $\alpha$-steranes and thermodynamically more stable isosteranes, which constitute the main mass of the steranes studied. The degree of catagenetic conversion of oils was determined according to the ratios $\Sigma \mathrm{nC}_{13}-\mathrm{nC}_{15} / \Sigma \mathrm{nC}_{25}-\mathrm{nC}_{27}, \Sigma \mathrm{isoC}_{19}$ iso $\mathrm{C}_{20} / \Sigma \mathrm{nC}_{17}-\mathrm{nC}_{18}, \alpha$-isosteranes, etc.

Studies of relict hydrocarbons of Georgian oils have revealed the presence of known biomarkers - saturated relict structures, peculiarity in composition, quantitative and relative distribution of individual biomarkers and their various geochemical ratios that give reason for a more thorough study of the genetic code of Georgian oils.

\section{REFERENCES}

1. Geoffrey Eglinton, Mary Teresa Joseph Murphy. Organic Geochemistry: Methods and Results. Publisher: Springer; Softcover reprint of the original 1st ed. 1969 edition (May 23, 2013), 828p. ISBN10: 3642877362; ISBN-13: 978-3642877360.

2. Tissot B.P., Velte D.H. Formation and Propagation of Oil. Springer-Vera Berlin Heidelberg, 1984, 702p., ISBN 978-3-642-87813-8; DOI 10.1007/978-3-642-87813-8.

3. Engel M.H., Macko S.A. Organic geochemistry: principles and applications, Plenum Press, New York; 1993, 861p. ISBN 978-1-4615-2890-6; DOI 10.1007/978-1-4615-2890-6.

4. Parviz Darvishi, Dariush Mowla, Shahab Ayatollahi. Experiomental and Teoretical Investigation of Biodegradation. LAP LAMBERT Academic Publishing, 2011, 172p. ISBN-10:3844325638.

5. Bazhenova O.K. Geology and Geochemistry of Oil and Gas. Moscow, “Academy”, 2004, 415p. 
6. Peters K.E., Walters C.C., Moldovan J.M. The biomarker guide. Cambridge University Press; edition 2, 2005, 700p. ISBN-10: 0521837626; ISBN-13: 978-0521837620.

7. Brocks J.J., Summons R.E. Sedimentary hydrocarbons, biomarkers for early life. Treatise on geochemistry, Biogeochemistry. Amst. Boston, 2013, v. 10, pp.61-103. Amsterdam, Netherlands: Elsevier, https://doi.org/10.1016/B978-0-08-095975-7.00803-2.

8. Topuria E.N., Lekveishvili E.N., Khetsuriani N.T., Edilashvili I.L. Investigation of hydrocarbon content of middle and high boiling fractions of Georgian oils by methods of mass- and chromate-mass-spectrometry. Mass-Spectrometry, 2007, v. 4, No. 3, pp.197-226. Retrieved from http://www.vmso.ru.

9. Topuria E.N., Khetsuriani N.T, Tretiakov K.V., Gonzalez C.A., Mikaia A.I. GC-MS Study of Polycyclic Saturated Hydrocarbons in High-Boiling Fractions of Georgian Oils. Eastern Analytical Symposium and Exposition, Analytical in Motion. 2013, November 18-20, New Jersey.

10. Petrov Al.A. Hydrocarbons of Oil. Moscow: "Nauka", 1984, 264p.

11. Topuria E.N., Usharauli E.A., Kortava L.M., Mchedlishvili I.J., Skhirtladze N.N., Gverdtsiteli D.D., Edilashvili I.L. Chemical typification of Taribani and Satskhenisi oils. Georg. Eng. News, 2003, No. 2, pp.175-180.

12. Serebrennikova O.V., Chekhovski F., Belitskaya E.A. Composition of biomarkers in organic substance of Triassic rocks from the south of the Western Russia. Chemistry of oil and gas: materials of the International conference, Tomsk, V.Y. Zuev Institute of Atmospheric Optics of the Siberian Branch of the Russian Academy of Sciences. 2006, v.1, pp.109-112.

13. Topuria E.N., Khetsuriani N.T., Edilashvili I.L., Skhirtladze N.N. Separation of Paraffin-Naphthene Hydrocarbons of $250-350^{\circ} \mathrm{C}$ Oil Fraction by Thermal Diffusion Method. Georgian Chemical Journal, 2005, vol.5, \#6, pp.565-570.

14. Topuria E.N., Khetsuriani N.T. (2011) Materiali IX Mezhdunarodnoi Massspectrometricheskoi Konferencii Po Neftekhimii, Ekologii I Pishchevoi Khimii, pp.143-151.PETROMASS-2011, M. (in Russian).

15. Topuria E.N., Khetsuriani N.T., Lekveishvili E.N., Mchedlishvili I.J. Thiocarbamid Extraction of $\mathrm{C}_{10}-\mathrm{C}_{16}$ polycyclic naphtenes from oils. Georgia Chemical Journal, 2009, v. 9, No 6, pp.521-524.

16. Khetsuriani N.T., Topuria E.N., Chkhaidze M.N., Tsitsishvili V.G. Polycycloal-kane Hydrocarbon in Taribani Oil. World Science (Multidisciplinary Scientific Edition), Warsaw, Poland, 2018, \#9 (37), pp.3341. Retrieved from https://doi.org/10.31435/rsglobal_ws/30092018/6132

17. Kimble B.I., Maxwell J.R., Philp R.P., Eglinton G. Identification of steranes and triterpanes in geolipid extracts by high-resolution gas chromatography and mass-spectrometry. Chem. Geol. 1974, v.14, pp.173-198.

18. Dididze A.V., Pustilnikova S.D., Arefiev O.A., Petrov Al.A., Investigation of individual composition of high-molecular hydrocarbons of Georgian oils. Neftechimia, 1979, v.19, No. 3, pp. 336-343. Retrieved from http://evagrand.ru/dlya/zhurnal-neftepererabotka-i-neftehimiya.html

19. Alexander R., Kagi R., Noble R. Identification of the bicyclic sesquiterpenes drimane and eudesmane in petroleum. Chem.Soc., Chem.Commun. 1981, v5, pp.226-228. DOI:10.1039/C39830000226

20. Richardson J.S., Mulle D.E. Identification of dicyclic and tricyclic hydrocarbons in the saturate fraction of a crude oil by gas chromatography/mass spectrometry. 1982, Anal. Chem. 54, 765-768. DOI: $10.1021 / \mathrm{ac} 00241 \mathrm{a} 037$

21. Vorobiova N.S., Zemskova Z.K., Petrov Al.A. Polycyclic naphtenes of $\mathrm{C}_{14}-\mathrm{C}_{26}$ composition in oil from Siva deposit. Neftekhimya, 1978, v.18, No 6, pp.855-863. ISSN 0233-5727; http://evagrand.ru/dlya/zhurnal-neftepererabotka-i-neftehimiya.html

22. Tsitsishvili V.G., Topuria E.N., Khetsuriani N.T., Dididze A.V., Mchedlishvili I.J. About biomarkers in some Georgian oils. Theses of the VII Baku international Mamedaliev conference dedicated to the 80th anniversary of the Institute of petrochemical processes of the Azerbaijan National Academy of Sciences, 2009, September 29-October 2, pp.135-136.

23. Gordadze G. N., Poshibaeva A. R., Giruts M. V., Perevalova A. A., and Koshelev V. N. Formation of Petroleum Hydrocarbons from Prokaryote Biomass: 1. Formation of Petroleum Biomarker Hydrocarbons from Thermoplasma sp. Archaea Biomass. ISSN 0965-5441, Petroleum Chemistry, 2018, Vol. 58, No. 3, pp. 186-189. DOI: 10.1134/S096554411803009X

24. Topuria E.N., Khetsuriani N.T., Lekveishvili E.N., Dididze A.V., Gabunia T.I. Relict hydrocarbons in Georgian oils. Proceedings of the Georgian National Academy of Sciences, 2008, 34(3), pp.321-329. 